\title{
A Sociolinguistic Approach of Taboo Words in Moroccan Society
}

\author{
Khalid Houssaini, PhD \\ Sidi Mohamed Ben Abdellah University, Fès, Morocco
}

Doi:10.19044/esj.2019.v15n29p37 ～URL:http://dx.doi.org/10.19044/esj.2019.v15n29p37

\begin{abstract}
Taboo can be characterized as being concerned with behavior which is believed to be supernaturally forbidden or regarded as immoral or improper. Taboo, in language, is associated with things which are not said, and in particular with words and expressions which are not used. This paper is concerned with a sociolinguistic analysis of taboo phenomenon in Moroccan society. In other words, it tries to combine societal and situational factors together to see how they influence taboo. Taboo words are examined and explained in their sociocultural and communicational contexts. In other words, they are treated as dynamic phenomenon in the Moroccan society. For this reason, the paper suggests a contextual framework for the analysis of taboo words in Moroccan culture. It discusses the creation, violations and the use of euphemism for taboo language. A questionnaire survey is administered to a random population sample of 200 adult Moroccan respondents to elicit their views and attitudes on the use of taboo words and on strategies they adopt to use euphemistic devices. The findings reveal a close correlation between the use of taboo words and euphemism and their contexts of use. These findings indicate that the use of linguistic taboo and euphemism differ from one individual to another depending on their age, gender, educational background and the context of use. General conclusions and discussion are drawn to encourage future studies on taboo as a cultural and linguistic phenomenon.
\end{abstract}

Keywords: Taboo language, Ethnography of Communication, Register, Euphemism

\section{Introduction}

The concern of the present paper is to try to shed light on taboo words in Moroccan society. Therefore, it attempts to apply some theories of sociolinguistics to the analysis of taboo words in Moroccan society. Halliday's notion of register (1989), Dell Hyme's analysis of speech events (1972) and other sociolinguistic insights will help us understand taboo phenomenon. 
Taboo words will be examined and explained in their sociocultural and communicational contexts. In other words, they will be treated as dynamic phenomenon in the Moroccan society. For this reason, the paper suggests a contextual framework for the analysis of taboo words in our society. It discusses the creation, violations and the use of euphemism for taboo language.

Taken collectively, the paper is divided into some sections: The first sections discuss different aspects of taboo words in Moroccan society, the creation and violations of taboo words. The other sections deal with taboo and sexism and the use of euphemism, namely the use of euphemistic devices by Moroccan people to avoid using taboo words.

\section{Methodology}

To examine taboo words in their communicational and sociocultural contexts and with respect to data collection, a questionnaire survey is administered to a random population sample of Moroccan respondents who are adults, from both sexes and from different social educational and cultural backgrounds. The focus is on the use of taboo words in Moroccan society and also on the use of euphemisms to avoid using taboo words. Respondents are asked attitudinal questions concerning taboo words to see how people react to the use of these words. Questions of the creation and the violation of taboo words in relation to both sexes and the different strategies they adopt to use euphemistic devices to mention taboo words are also highlighted.

The choice to elucidate peoples' attitudes is justified by the belief that their views and opinions are far more important in understanding taboo phenomenon in Moroccan society.

The questionnaire is administered to 200 adult Moroccan respondents. The sampling population is representative based on ethnic, educational, social and cultural differences traits of the respondents.

The steps of the methodology run as follows :

a- Selecting respondents randomly from both sexes, different ages and different educational backgrounds,

b- Collecting data through the administration of a questionnaire to a random population of respondents, and

c- Describing results statistically through percentages in order to facilitate interpretation and to look for correlations between taboo words and their sociocultural and communicational contexts.

As indicated in the table below, the selected population or sample itself is a heterogeneous community with great diversity in terms of education, gender, age and ethnicity. 
Table 1: Information about Questionnaire Respondents

\begin{tabular}{|l|l|l|l|l|l|l|l|l|l|l|}
\hline & \multicolumn{4}{|l|}{ Age } & \multicolumn{4}{l}{ Sex } & \multicolumn{3}{l|}{ Education } & Total \\
\cline { 2 - 10 } & $18-25$ & $26-30$ & $31-35$ & $36-40$ & 41 or more & Male & Female & Educated & Uneducated & \\
\hline $\begin{array}{l}\text { Moroccan } \\
\text { Respondents }\end{array}$ & 44 & 16 & 40 & 40 & 60 & 120 & 80 & 110 & 90 & 200 \\
\hline Percentage & $22 \%$ & $8 \%$ & $20 \%$ & $20 \%$ & $30 \%$ & $60 \%$ & $40 \%$ & $55 \%$ & $45 \%$ & $100 \%$ \\
\hline
\end{tabular}

\section{Aspects of taboo words in Moroccan Society: Origin and nature}

Etymologically, taboo (also written Tabu and Tapu) is a Polynesian word. It is the name given by Polynesian people to a system of religious prohibitions. Those prohibitions, however, do occur in all societies under different names.

But it is important to note that whereas ancient taboos stemmed mainly from an ordinary sense of sacredness implying no moral quality at all, modern taboo in their most essential meaning refer to the behavior which is "believed to be supernaturally forbidden or regarded as immoral or improper" (Trudgill, 1974 : 29).

Accordingly, this primary use of taboo, as stated by Trudgill, qualifies taboo as involving both moral and religious qualities. 'Taboo restrictions', writes Freud (1936) 'are nothing but just moral or religious prohibitions' (Totem et Taboo : 29).

Taboo, therefore, is acknowledged as a behavior which is associated with superstition, custom, and supernatural power. In language, however, taboo is related to words and acts which are not said and not used, at least, in public.

In Moroccan society, taboo implies both moral and religious aspects. The two terms /hra:m/ "sacred" and $/ \mathrm{h} f \mathrm{u}: \mathrm{ma} /$ "shameful" designate the significance of taboo prohibitions in Moroccan society. Now, if a word or act is seen as taboo, a series of adjectives like unclean, impure, shameful, forbidden, and sacred, emerge to say that it must not be mentioned or talked about. Consequently, taboo as a sociocultural phenomenon becomes a linguistic phenomenon as well.

In this brief introduction, the focus has been on taboo origin and nature. The subsequent sections will discuss the creation, violations of taboo language and the use of euphemism in Moroccan society.

\section{The creation of taboo words in Moroccan Society}

It is mentioned that taboo in Moroccan society implies both moral and religious values. One can, therefore, deduce that the most tabooed words in Moroccan society are those which are associated with sacredness and also those which are placed on sexual morality. 
The types of Moroccan taboo words, following this meaning, can be classified and divided into two major categories: taboo words related to (a) religion, (b) morality.

\section{Taboo words associated with sacredness}

In Moroccan society, words which have religious connotations involving the names of Allah, i.e. God, the prophets, and the holy places are considered sacred, thus, it is forbidden to take them in vain. For example, an utterance like /llah jenzal di:n mmok/ 'May God damns your mother's religion' is considered like a blasphemy and insult towards the religion and people may be shocked to hear such sacred words be used in careless and informal contexts.

It is important to note, however, that because taboo words are shocking and strong, they are often used by Moroccan people, especially among young people, as swear words.

Taboo words in the above example are uttered to serve a swearing function rather than a blasphemous one. The intention of the speaker (transgressor) is to be more provocative and more aggressive rather than to attack religion.

Swearing generally indicates group membership, a person often swears in front of people he knows well, who belong to his own social circle, age, sex, social status...etc.

Preston (1989) states that 'most so called secret languages...turn out to function more for the purposes of in-group solidarity than public deception'. (Preston, 1989 : 206).

The notion of sacredness is not limited to religious beliefs; it also includes that supernatural power which is embodied in superstition.

The interaction between superstition and language has turned many words related to unpleasant matter into taboo words. Words associated with /jnu: $\mathrm{n} /$ 'devils' and /shu: $r$ / 'magic' constitute the set of superstitious taboo words. Moroccans, especially those brought up in traditional and uneducated families are reluctant to talk about the devils straightforwardly for fear of a supernatural calamity.

Parents control the speech and action of their children by advising them not to talk about the devils and not to pour boiled water in the lavatory, especially at night. They behave likewise to provide the antidote to superstition and fear.

It is worth mentioning that the Moroccan citizen is still troubled and frightened by the world of the unknown. Yet, it is apparent that the educated Moroccans have begun to free themselves from superstition. Older and uneducated respondents still believe that we should avoid talking openly and 
carelessly about unpleasant matters, namely the devils and magic; a belief which is less emphasized by educated respondents.

It remains to indicate that $25 \%$ of my informants classify taboo words associated with sanctity as among the most severe taboo words in Moroccan society.

\section{Taboo words associated with morality}

In Moroccan society, words related to sex, sex organs, and some words related to the elimination of body wastes are regarded as shocking, dirty and mainly immoral, therefore, they become tabooed.

In Moroccan society, sex is seen as a harsh and private topic. The realm of sex is secret and unspeakable. People would enter this tabooed realm only in whispering. Words which are related to sex and sex organs are avoided because of their obscenity and because also of a strong attitude about them among the general public. Nevertheless, these words are no longer avoided if they are uttered among intimate friends or within a specific context of use. It is necessary, then, for anyone to know to whom, when and in what manner such words can be accepted.

Another type of words which are tabooed in Moroccan society is those which are connected with bodily functions. Words like /lbu: 1/ 'urine', /lxəra/ 'excrement', and others are seen as dirty and, thus, they are avoided and replaced by euphemistic devices with the same meaning. In Moroccan Arabic, the expressions / yadi lmirha: $\mathrm{d}$ / or /yadi lbi: $\mathrm{t}$ lma/ 'going to the toilet' fulfill the same meaning as 'to urinate' or 'to defecate' .

As shown in the pie chart below, the majority of my informants $(75 \%)$ agree that taboo words related to sex and sex organs are the most severe taboos in Moroccan society, followed by those connected with sanctity.

Figure 1: Informants' views about the most Offensive Taboo Words

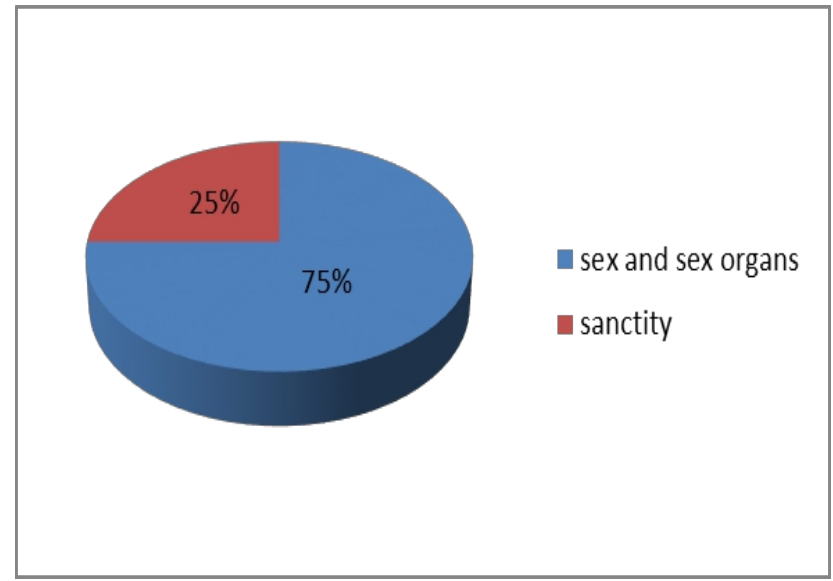


To sum up, this section has attempted to show how taboo words come into being in Moroccan society. It has also tried to provide some example of those obscene words which are avoided.

\section{Taboo violations in Moroccan society}

Moroccan people violate and break taboo words for a variety of reasons. Some of these reasons along with conditions under which violations are carried out are what this section will try to investigate. Violations can be intentional or unintentional. There are many types of taboo violations in Moroccan Arabic; but the focus is on two major types which will provide a clear idea about this transgression.

\section{Violation for communicative purposes}

In Moroccan society, taboo words which are related to medical terms are uttered openly. It is permitted to a doctor to use taboo words when s/he gives medical instructions to his patients and they do not feel offended at all. The use of euphemistic devices, in this case, is not desirable because euphemisms may not fulfill the requirements of communication. In a similar way, a religious man is given the right to speak openly using taboo words provided that his aim is to clarify the religious instructions.

It is important to note that these intentional violations are legitimized only when some conditions of communication are met. These conditions are simply to know who, when, for what end, and how the violation is to be accepted. Violation is permitted only for good ends, that is, to advice, to explain and by the right persons in the right place and time. A part from these conditions, any violation is regarded as a transgression against social norms and it may cause shock and embarrassment.

\section{Violation in daily conversation}

Violation in everyday conversation could be intentional or unintentional. Telling jokes is one good example of this intentional violation. Moroccan young people are known by telling jokes which are related to tabooed topics. The violation of these taboo words can be seen as a means of identification by the same social groups who have the same knowledge of the sociolect (Halliday, Michael A.K. 1989).

One major type of unintentional violation is that of a child who utters taboo words without knowing their connotations. There is also the case of a person who says something which is not meant to be a joke, but which seriously upsets the people he is talking to.

Generally violations in daily conversations can be used in order to assert one's membership within a group one's own. Intentional violation is a 
device whereby one incites others to converse and communicate with him/her openly and freely.

The concern of this section has been to provide some general account of taboo violations in Moroccan society. In the following section, the discussion focuses on taboo words and sexism. In other words, the question is to know to what extent the speech of Moroccan females differs from that of males as far as taboo language is concerned.

\section{Violation and sexism}

In Moroccan society, the language of men differs remarkably from that of women. The woman in Moroccan culture is considered as a sensitive being. Therefore, and at the level of speech, women use the prestigious forms more often than men do. Ennaji and Sadiqi (1992) state that 'this tendency' of women to speak 'clean' 'is due to the fact that women pay more attention to social status than men do' (Ennaji and Sadiqi, 1992 :80).

Another sociolinguistic reality behind this difference is found in Downes (1984) who asserts that because of women's subordination, they are pushed towards 'the overt linguistic signals of prestige as a form of compensation' (Downes, 1984 :180).

However, a Moroccan woman may use taboo words only to assume stereotyped masculine values such as roughness and toughness.

It is worth mentioning that when a woman utters taboo words, it is always those taboo words which are associated with either bodily functions or unpleasant matters. You could hear, for instance, an angry or shocked woman says /lxora/ 'excrement', but rarely could you hear her use blasphemous words or taboo words related to sex or sex organs. This appears to be due to the fact that 'men and women are socially different in that society lays down different social roles for them and expects different behavior patterns from them' (Trudgill, $1974: 88$ ).

It is noteworthy to say that although women's speech may be looked upon as generally 'clean' because of the women awareness of their social status, it is this linguistic 'status-consciousness' which reflects women's subordination in social life.

To sum up, one may agree with Fasold (1990) who states that 'there are ways of speaking which men use to emphasize their masculinity and other forms women use to symbolize feminity' (Fasold, 1990 : 99). This sexist attitude which language reflects prevents women from expressing themselves openly with feeling. In other words, their individuality is never publicly revealed.

It remains to indicate that almost all my respondents, males and female, agree that men make use of taboo words more than women do. The following graph displays this: 
Figure 2: Respondents' attitudes towards Taboo Usage among Men and Women

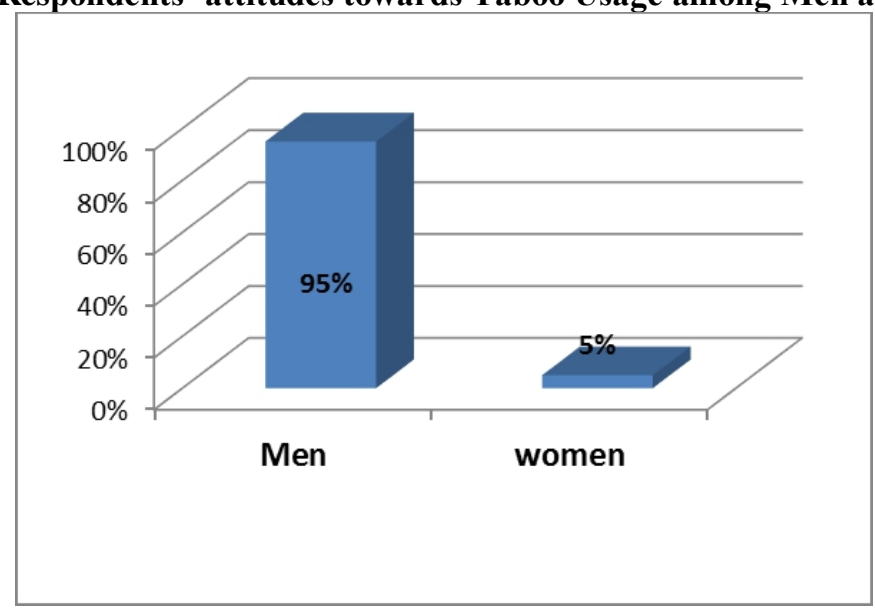

\section{Taboo and Euphemism}

The aim of this section is to consider the use of euphemism as a device which allows Moroccan people to mention taboo words and expressions and attempts to make them sound acceptable by neutralizing their unpleasantness. In other words, euphemistic devices which are concerned with ways of avoiding or replacing taboo words are highlighted.

\section{Euphemistic devices in Moroccan Society}

In Moroccan Arabic, there appears to be many euphemistic devices among which the following techniques are considered to be major ones.

Substitution is a device whereby Moroccans replace taboo words by alluding to them euphemistically. For example, /lzada Jahriya/ 'the monthly habit' refers to menstruation./lzada sirrija/ 'the secret habit' is another example which refers to masturbation. Similar substitutions exist to replace the verbs 'to urinate' and 'to defecate'. Thus, expressions like / yadi lbi: t lma/ or /yadi lmirha: d/ fulfill this meaning of bodily functions. Ennaji and Sadiqi (1992) give another example of euphemism which is used by Moroccan rural women. These women instead of referring to their husbands by their first names, they use expressions such as /huwa/ 'he/him', /rajli/ 'my man/my husband' or /mu:l dda:r/ 'owner of the house/home'.

Omission is another euphemistic device in Moroccan Arabic. The speaker who wants to mention a taboo word may delete it and utter in its place one of the two words /hr: am/ 'sacred' and /hfu: ma/ 'shameful' which are the two qualities that the meaning of our taboo implies.

Ambiguous words and expressions serve also as euphemisms to talk about taboo words and expressions. For instance, 'aids' and 'cancer' are mentioned by /lmard lqbi: h/ 'the horrible disease'. 
Silence is another device whereby Moroccan people decide to refrain from speech rather than to mention taboo words. Silence, however, in case of taboo situations, is determined by attitudes of the participants and also by their relationships to each other which is labeled by social roles among individuals, that is man/woman, inferior/superior relationships. Here, it is important to stress situations under which who speaks to whom and in what manner. Taboo words are used under strict conditions of use or rules of use and by appropriate persons.

The pie chart below highlights that the majority of my respondents favor the use of euphemism whenever they mention taboo words.

Figure 3: Informants' attitudes towards the Use of Euphemism

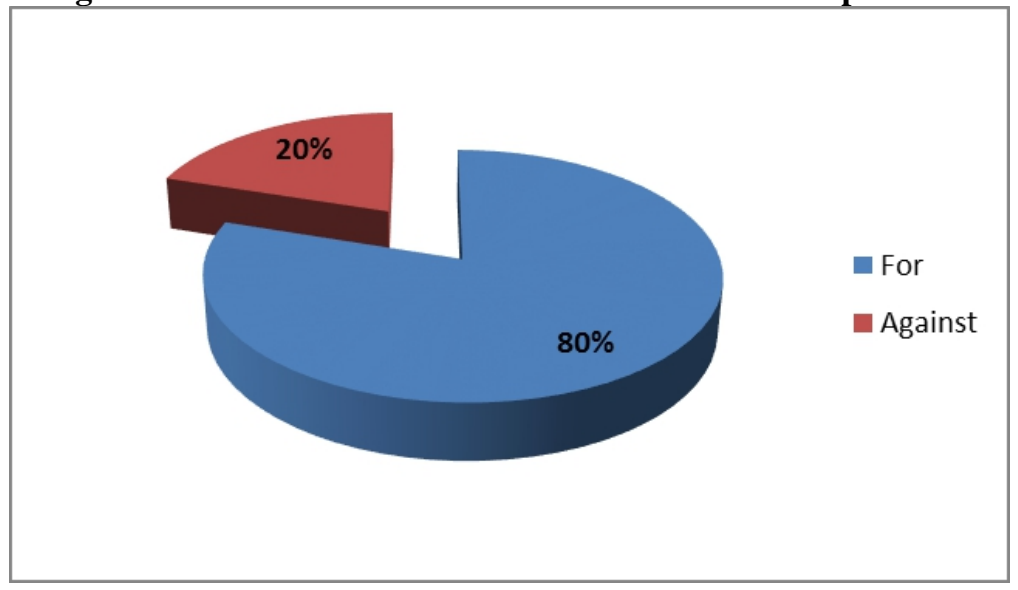

\section{Taboo words and code-switching}

There are language euphemisms which seem to arise from situational switching. Code-switching is the result of two or more languages in contact. Code-switching is, therefore, defined in terms of bilingualism and multilingualism. The majority of Moroccan people are either bilinguals or multilinguals. Therefore, the speaker who is literate in one or more languages can switch to another language when s/he wants to mention taboos. For instance, bilingual educated patients and doctors very often switch to French to indicate taboo words. In this respect, a bilingual has more choice to talk about taboo words without appearing vulgar than a monolingual. As a result, for the speaker to switch from code A to code B to mention taboo words, this can be seen as an act of respectability and a sign of prestige. These taboo words become acceptable and they lack their social connotations, they remain only with denotative meanings. For example, instead of saying /qahba/ 'a whore', the speaker switches to say 'prostituée' in French. This situational codeswitching is used to mitigate the strength of the taboo word, and probably to avoid offending listeners. 
It is worth mentioning that there are some people, especially elderly uneducated people, who regard the switching itself as 'shameful', that is, taboo. For some of them, the switching from Moroccan Arabic, for instance, to French is considered as a taboo act, French is associated with colonialism and alienation. In this respect, it is important to know the attitudes of participants and their relationships to each other before one decides to switch to another language to mention taboo words as a kind of circumlocution (Dell Hymes 1972 \& 1986).

As shown in the graph below, most of my respondents prefer to use euphemistic devices to mention taboo words than to code switch to another language for the same purpose.

Figure 4: Strategies adopted to use Taboo Words

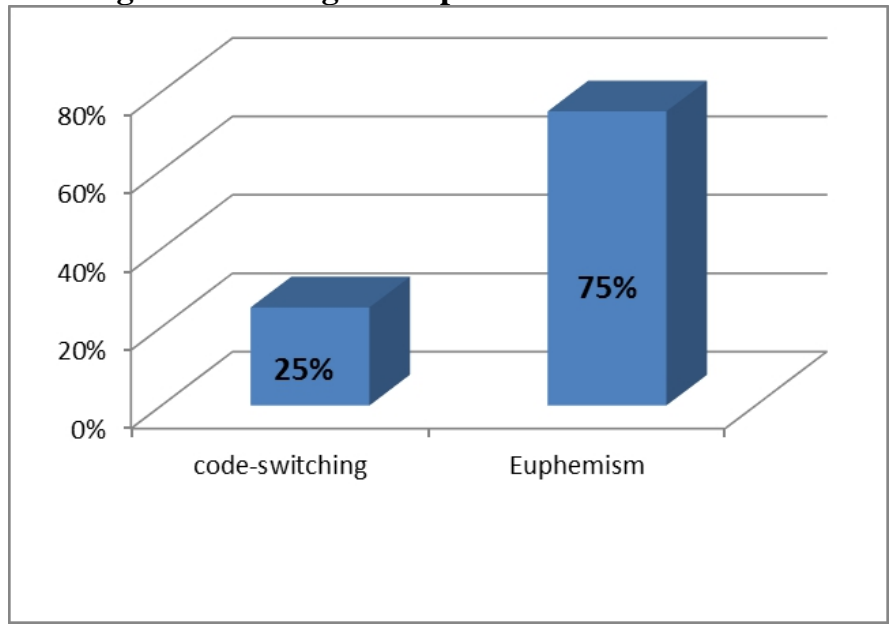

To conclude, the main achievement of this section has been its attempt to relate taboo words to some varieties of language situations, that is code-switching and bilingualism.

\section{Implications and discussion}

Taken together, despite one's concerns about the sample, about respondent selection, and about questionnaire design and implementation, the study has yielded some valuable conclusions or results concerning the use of taboo words and taboo violations in Moroccan society and the use of euphemistic devices to avoid using them in public that can be summarized as follows:

The study has found that the most tabooed words in Moroccan society are those which are associated with sacredness and those which are placed on sexual morality. In other words, most of my informants classify words associated with sexuality as among the most severe taboos in Moroccan 
society. In other words, words related to sex, sex organs and bodily wastes are regarded as immoral and, therefore, a great emphasis is placed on them.

In the same vein, all respondents agree that men make use of taboo words more than women do in Moroccan society. Violation of taboo words can be explained by the social fact that the language of men differs remarkably from that of women since society lays down different social roles for them and expects different behavior patterns from them.

It is also found that the violation of taboo words for a communicative purpose seems to make taboos appear less strict since their use becomes permissible. Taboo words which are related to medical terms and religious subjects are uttered openly by doctors or religious men because the use of euphemistic expressions in these contexts may be misinterpreted or misunderstood.

The investigation also reveals that men and women speak differently when it comes to the use of taboo words. By the same token, women make use more often of euphemistic expressions to avoid or replace taboo language (Coates, J. 2004 ).

Respondents agree that educated people use code switching to mention taboo items. In other words, speakers switch to another language, especially French, to talk taboo to attenuate the social effect of taboo language and avoid offending listeners. Besides, it is worth mentioning that sex topic is still the most sensitive and fearful subject which people try to avoid mentioning in public. In fact, most people feel reluctant when dealing with sex topic, therefore, sex topic is mentioned euphemistically by people in order not to harm their relationships.

The study indicates that the respondents' attitudes towards taboos differ from one individual to another depending on their age, gender, educational background and the context of use. The context, in which language is used, has also a great importance. Thus, language and the context of use are inseparable. This means that there are social factors which play a crucial role in directing language use between speakers. In other words, the use of language depends largely on the social context where interaction takes place. Consequently, there are some aspects that affect language including the social structure, the social environment and values of the society (Jay, T. 2009).

What also emerged from the study is that the use of taboos exists side by side with euphemism depending on the context of communication. Indeed, Moroccan people are careful in approaching certain topics related to sexual matters and sacredness since the majority of them do not show any direct reference to such topics, unless they are violated for some reasons.

It is important to note that holy or sacred taboos are settled by ritual interdictions. People form strict rules governing taboo words with sacred 
connotations. In Moroccan society, for instance, it is forbidden to "take the Lord's (Allah) name in vain". As a result, taboos which are related to sacredness are believed to hold a magical power and people do not speak or act taboo to avoid divine anger or supernatural calamities. In addition, whenever a taboo is used or said, it becomes associated to the impure or the profane, namely it enters the prohibited zone. The sacred, however, is forbidden to be used in vain because of its purity. So, taboo must not be used so as not to confuse the sacred and the profane that is to mix the pure with the impure.

Why is it that the most severe taboos are those which are related to sex and sex organs?

A good answer can be found in psychology which makes us understand that the nature of man is biological, that man is born with certain instinctual drives, most notably impulses toward self-gratification and sexual impulses. But, by taboo prohibitions on sex 'which stands for all pleasure', society force into the unconscious these sexual desires which are apparently in conflict with accepted norms of social behavior. Trudgill (1974) states that this prohibition 'is a reflection of the great emphasis traditionally placed on sexual morality in our culture' (p.30).

It is mainly highlighted that the framework of analysis applied to taboo phenomenon, namely the micro context or situational, factors has helped a lot in the understanding of taboo words by putting them in their sociocultural and communicational contexts in Moroccan society.

It remains to indicate that these attitudes and perception patterns about taboo language are not static. They may change in response to other new sociocultural and communicational contexts or new environmental stimuli. The findings reported in this paper must be interpreted with caution. It is for this reason that the goal of the present study is to provide a preliminary account or analysis of taboo phenomenon in Moroccan society that may stimulate additional inquiry and investigation.

\section{Conclusion}

So far, the concern of the present paper is a sociolinguistic analysis of taboo phenomenon. Accordingly, the study has attempted to analyze the situational factors that influence taboo words.

The first section has tried to account for taboo aspects in Moroccan society. The other sections have emphasized the creation, violation of taboo words, as well as sexist attitudes towards them. Then, the focus has been on examining the use of euphemism as a device whereby Moroccan people avoid mentioning taboo words directly. Some euphemistic devices adopted by Moroccan people to use taboo words, like code-switching, silence and omission are also emphasized. 
The general aim of this paper has been to relate taboo phenomenon to society. Taboo is generally acknowledged to be a sociocultural and linguistic phenomenon.

Finally, it is worth mentioning that no matter what one has said about taboo, it remains a subject which promises new horizons to be explored. But it is the hope that this modest paper will contribute to the understanding of taboo as a sociocultural and sociolinguistic phenomenon.

\section{References:}

1. Allan, K., and Burridge, K. (2006). Forbidden Words: Taboo and the Censoring of Language. Cambridge: Cambridge University Press.

2. Bernard, R. H. (2000). Social Research Methods: Qualitative and Quantitative Approaches. London: Sage Publications, Inc.

3. Brown, G. (1995). Speakers, Listeners and Communication: Explorations in

4. Discourse Analysis. CUP: Cambridge.

5. Brown, G. and G. Yule (1983). Discourse Analysis. CUP: Cambridge.

6. Coates, J. (2004). Women, Men, and Language: A Sociolinguistic Account of Sex Differences in Language. London: Pearson Longman.

7. Downes, W. (1984). Language and Society. Fontana Paperbacks: London.

8. Edwards, A. (1994). Techniques of Attitudes Scales Construction. New York: Irvington Publishers, Inc.

9. Ennaji, M. and F. Sadiqi (1992). Introduction to Modern Linguistics. Afrique- Orient: Casablanca.

10. Epstein, J. (1985). 'Sex and Euphemism' in Enright, D.J. (ed) Fair of Speech: The Uses of Euphemism. OUP: Oxford.

11. Fasold, R. (1984). The Sociolinguistics of Society. Basil Blackwell Ltd: Oxford.

12. Freud, S. (1999). Totem and Taboo.Trans. James Strachey. London: Routledge.

13. Halliday, Michael A.K. (1989). Spoken and written language. Oxford: Oxford University Press.

14. Huang Hongxu and Guisen Tian (1990). 'A sociolinguistic view of linguistic taboo in Chinese'in International Journal of the Sociology of Language, 81: 63-85.

15. Hudson, R.A. (1980). Sociolinguistics. CUP: Cambridge.

16. Hymes, Dell. (1972). 'Models of the interaction of language and social life'. In J.

17. Gumperz \& D. Hymes (eds). Directions in Sociolinguistics: The

18. Ethnography of Communication. New York etc.: Holt, Rinehart \&Winston, pp.35-71. 
19. Jay, T. (2009). "The Utility and Ubiquity of Taboo Words". Respective on

20. Psychological Science, Vol. 4, pp. 153-161. Massachusetts College Literal Arts.

21. Khursheed, A., Ghani, M., Alam, A., and Gul, T. (2013). "A Sociolinguistic Study of the Linguistic Taboos in the Pashtoon Society". Journal of International Researchers, V. 2, N. 1, pp. 36-41.

22. Labov, W. (1972). Sociolinguistic Patterns. University of Pennsylvania Press: Philadephia.

23. Maxwell, J. A. (1996). Qualitative Research Design: An Interactive Approach (Applied social research methods series: Vol. 41). Thousand Oaks, CA: Sage Publications.

24. Mills, S. (2003). Gender and Politeness. Cambridge: Cambridge University

25. Press,UK.

26. Nachmias, C. \&Nachmias, D. (1987). Research methods in the social sciences. Edward Arnold.

27. Oppenheim, A. N. (1992). Questionnaire design, interviewing and attitude

28. measurement. London: Pinter.

29. Preston, D. R. (1989). Sociolinguistics and Second Language Acquisition.

30. Basil Blackwell Ltd: Oxford.

31. Pride, J.B. and J. Holmes (eds) (1972). Sociolinguistics. Penguin Books Ltd:

32. Harmondsworth.

33. Sadiqi, F. (2003). Women, Gender and Language in Morocco. Leiden, Boston: Brill.

34. Stoke, E. (2005). "Analysing Gender and Language". Journal of Sociolinguistics, Vol. 911, pp. 118-133.

35. Trudgill, P. (1974). Sociolinguistics: An Introduction to Language and Society.Pelican Books: England.

36. Wardhaugh, R. (1986). An Intoduction to Sociolinguistics. Basil Blackwell Ltd: Oxford.

37. Watts, J. R. (2003). Politeness. Cambridge: Cambridge University Press. 